\title{
Mechanical Properties of Recycled PET Fibers in Concrete
}

\author{
Fernando Pelisser ${ }^{\mathrm{a}}$, Oscar Rubem Klegues Montedo ${ }^{\mathrm{a} *}$, \\ Philippe Jean Paul Gleize ${ }^{\mathrm{b}}$ Humberto Ramos Roman ${ }^{\mathrm{b}}$ \\ aUnidade Acadêmica de Ciências, Engenharias e Tecnologia - UNACET, \\ Universidade do Extremo Sul Catarinense-UNESC, Av. Universitária, 1105, \\ CEP 88806-000, Criciúma, SC, Brasil \\ ${ }^{\mathrm{b}}$ Departamento de Engenharia Civil, Universidade Federal de Santa Catarina - UFSC, \\ Trindade, CEP 88040-900, Florianópolis, SC, Brasil
}

Received: October 25, 2011; Revised: May 21, 2012

\begin{abstract}
Fiber-reinforced concrete represents the current tendency to apply more efficient crack-resistant concrete. For instance, polyethylene terephthalate (PET) is a polyester polymer obtained from recyclable bottles; it has been widely used to produce fibers to obtain cement-based products with improved properties. Therefore, this paper reports on an experimental study of recycled-bottle-PET fiber-reinforced concrete. Fibers with lengths of 10,15 and $20 \mathrm{~mm}$ and volume fractions of $0.05,0.18$ and $0.30 \%$ related to the volume of the concrete were used. Physical and mechanical characterization of the concrete was performed, including the determination of compressive strength, flexural strength, Young's modulus and fracture toughness as well as analysis using mercury intrusion porosimetry (MIP) and scanning electron microscopy (SEM). Flexure and impact tests were performed after 28 and 150 days. No significant effect of the fiber addition on the compressive strength and modulus of elasticity was observed. However, the Young's modulus was observed to decrease as the fiber volume increased. At 28 days, the concrete flexural toughness and impact resistance increased with the presence of PET fibers, except for the 0.05 vol.\% sample. However, at 150 days, this improvement was no longer present due to recycled-bottle-PET fiber degradation in the alkaline concrete environment, as visualized by SEM observations. An increase in porosity also has occurred at 365 days for the fiber-reinforced concrete, as determined by MIP.
\end{abstract}

Keywords: fiber-reinforced concrete, recycled PET, synthetic fibers, mechanical properties

\section{Introduction}

It is well known that the incorporation of low volume fractions ( 0.05 to $0.5 \%)$ of low-modulus synthetic fibers in concrete does not lead to increased strength, but it does enhance the cracking properties, fracture toughness and impact resistance of the material ${ }^{1-6}$. Polypropylene fibers, which are formulated and produced specifically for reinforced mortars and concrete, are the most popular because they are cost competitive and alkali resistant; moreover, at low volumes, no additional care is required in mix proportioning and the manufacturing technique ${ }^{6,7}$. In addition, properties of polypropylene-fiber-reinforced concrete can be significantly improved. Polypropylene fibers in concrete can be used to reduce spalling and to enhance the residual strength of heated concretes ${ }^{8}$. Mixtures containing between 0.2 to $0.5 \mathrm{vol} . \%$ polypropylene fiber were generally characterized by an increase in compressive strength ${ }^{9}$, whereas with 0.5 vol.\% fiber, the compressive strength of fibrous specimens at the age of 91 days increased by $15 \%$ compared with those of the reference sample.

Industrial processes generate many residues and by-products, such as the waste obtained from recycled bottles composed of polyethylene terephthalate (PET) strings.

*e-mail: oscar.rkm@gmail.com
These PET strings are collected, selected, and used for PET fiber production. The remaining portion of the strings can be industrially cut to form short, multi-filament-type fibers (approximately $30 \mu \mathrm{m}$ in diameter) for use in concrete as a substitute for polypropylene and asbestos fibers. This type of material contributes to the sustainable development of the construction industry through recycling and the production of lower cost materials. These fibers are used with the aim of increased fracture toughness after concrete hardening. Moreover, according to Fraternali et al. ${ }^{10}$, the concrete reinforcement with recycled PET fibers qualifies as a competitive technique for enhancing the thermal resistance, compressive and tensile strengths, and ductility of concrete.

PET is a polyester polymer. The addition of $1.0 \mathrm{vol} . \%$ of polyester fibers to concrete has been shown to yield a 75\%, 9\%, 7\% and 5\% increase in impact strength, split tensile strength, flexural strength and compressive strength, respectively ${ }^{11}$.

According to Johnston ${ }^{4}$, the durability of polyester in Portland-cement-based material is doubtful and controversial. Balaguru and Slatum ${ }^{12}$ performed flexural toughness measurements of polyester-fiber-reinforced concrete and concluded that polyester fibers are not durable in the alkaline environment of concrete. Wang et al. ${ }^{13}$ and 
Houget ${ }^{14}$ observed that polyester fibers lose strength rapidly in the cement matrix due to their hydrolysis and dissolution in an alkaline environment. Silva ${ }^{15}$ concluded that recycled PET fibers interact with $\mathrm{Ca}(\mathrm{OH})_{2}$ and Lawrence solutions, their surface becomes rough and phases identified as alkaline terephthalates precipitate. In this work, the tested amount of PET fibers (0.4 and 0.8 vol.\%) had no effect on the compressive, tensile or flexural strength of the mortars or their degradation inside the composite; however, the fracture toughness of the mortars in flexural tests increased when fibers were introduced. However, due to the degradation of the fibers inside the mortars, the toughness decreased with time. In their recent study, Won et al. ${ }^{16}$ verified that recycled PET-fiber-reinforced cement composites exhibit a reduced compressive strength in alkaline and sulfuric acid environments. They concluded that when a recycled PET-fiber-reinforced cement composite was exposed to an alkaline environment, progressive deterioration was observed on the PET fiber surface as the aging time increased. If the recycled PET fiber is exposed to an alkaline environment, its performance can be expected to be poor; when recycled PET-fiber-reinforced cement composite was exposed to salt or sodium sulfate environments, very little deterioration of the PET fiber surface occurred, and this deterioration did not progress with aging time. The reduction in the observed mechanical properties yielded values similar to those of the reference concretes, not indicating, according to the authors, fiber deterioration ${ }^{16}$. In this case, the durability tests were performed after 120 days. The ACI Committee $544{ }^{17}$ stated that "[...] there is no consensus on the long-term durability of polyester fibers in Portland cement concrete". and Johnston 4 claimed that "[...] the problem of fiber durability is complicated by claims that not all polyesters are subject to alkali attack, but the distinction between those that are and those that are not is unclear at present". For example, Jackel, who was cited by Wang et al. ${ }^{13}$, claimed success in the use of polyester fibers for Portland cement products, and when consulting the Internet, Portland cement product manufacturers that use polyester fiber can be easily found. Nevertheless, fibers are typically used in low amounts ( 0.1 to $0.5 \mathrm{vol} . \%)$ to minimize the effects of the plastic shrinkage in concretes, as durability tests are almost never performed.

The problem of fiber durability is complicated because polyesters are a large polymer family and not all of them appear to be subject to alkali attack ${ }^{4}$. Moreover, studies of their stability in Portland cement matrix are scarce.

The research reported herein focuses on the properties of recycled-bottle PET-fiber-reinforced concrete that are susceptible to the eventual long-term degradation of these fibers. These properties include impact resistance, flexural load-deflection behavior and porosity. Scanning electron microscopy (SEM) observations were also performed. Other mechanical properties that are less affected by the PET fibers, such as the compressive and tensile strengths and the modulus of elasticity, are also discussed. Additional properties, such as specific gravity, water absorption, and natural carbonation depth, can be found else where because they were not significantly affected by PET fiber addition nor did they provide evidence of PET fiber degradation in concretes $^{18}$.

\section{Experimental}

Preliminary studies indicated that the presence of a fiber volume greater than $0.30 \%$ in concrete causes serious problems concerning homogeneity and workability, even with the use of plasticizer additives ${ }^{18}$. Thus, the fiber volume fraction was divided into four levels: 0 (reference), $0.05,0.18$ and $0.30 \%$, corresponding to $0,0.64,2.25$ and $3.90 \mathrm{~kg}$ of fiber per $\mathrm{m}^{3}$ of concrete, respectively. Concrete mechanical tests were conducted after 28 and 150 days, and SEM analyses were performed after 150 and 365 days. The former was used to prepare the samples for all the tests in this study, whereas the latter was only used to perform the porosimetry test. MIP tests were performed after 28, 150 and 365 days for concrete with a $0.30 \%$ fiber fraction addition. Table 1 summarizes the PET fiber volume content and slump test of the concrete mixes for the compositions used in this work.

The mix proportions by weight of the concrete matrix are provided in Table 2. The sand used was local natural sand with a maximum size of $2.4 \mathrm{~mm}$ and a specific gravity of $2.6 \mathrm{~kg} \cdot \mathrm{dm}^{-3}$. The coarse aggregate was crushed limestone with a maximum size of $19 \mathrm{~mm}$ and a specific gravity of $2.64 \mathrm{~kg} \cdot \mathrm{dm}^{-3}$. The cement used was Portland cement CP-V-ARI according to Brazilian Standards NBR ${ }^{19}$ (high early strength, equivalent to ASTM cement type III) and its proportion in the concrete was $343 \mathrm{~kg} \cdot \mathrm{m}^{-3}$. A melamine formaldehyde resin plasticizer $(0.7 \%)$ was used such that the fiber-reinforced concretes achieved adequate workability and maintained the required water/cement ratio. The main physical characteristics of the recycled-bottle-PET fibers are listed in Table 3. PET fibers are straight with a smooth surface as illustrated in Figure 1. The reference

Table 1. PET fiber volume content and slump test of the concrete mixes.

\begin{tabular}{ccc}
\hline Mix codification & Fiber content, volume \% & Slump, $\mathbf{m m}$ \\
\hline 1 & 0 & 100 \\
2 & 0.05 & 155 \\
3 & 0.18 & 70 \\
4 & 0.30 & 50 \\
\hline
\end{tabular}

Table 2. Concrete matrix mix proportions.

\begin{tabular}{cc}
\hline Materials & Weight proportions \\
\hline Cement & 1 \\
Fine aggregate & 2.3 \\
Coarse aggregate & 2.7 \\
Water & 0.62 \\
\hline
\end{tabular}

Table 3. Physical properties of the recycled-bottle-PET fibers.

\begin{tabular}{cc}
\hline Type & Multifilament \\
\hline Length $(\mathrm{mm})$ & 20 \\
Density $\left(\mathrm{g} . \mathrm{cm}^{-3}\right)$ & 1.33 \\
Diameter range $(\mu \mathrm{m})$ & $25-30$ \\
Water absorption $(\%)$ & 3.3 \\
Vitreous temperature $\left({ }^{\circ} \mathrm{C}\right)$ & 62 \\
Fusion temperature $\left({ }^{\circ} \mathrm{C}\right)$ & 252.8 \\
\hline
\end{tabular}




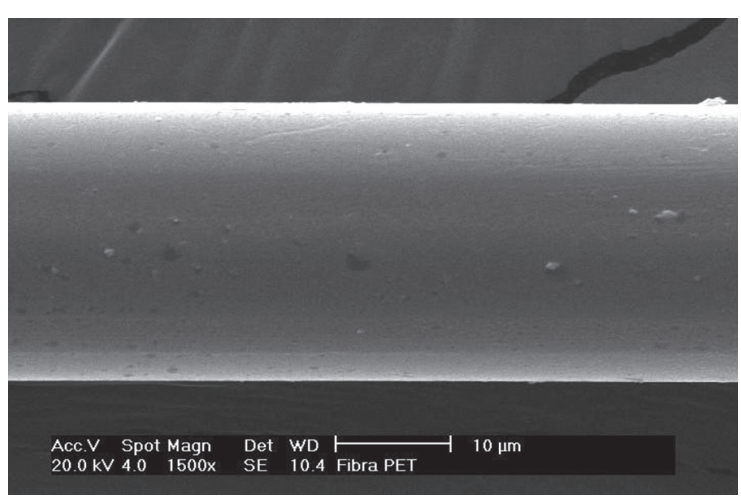

Figure 1. SEM micrograph of a recycled-bottle-PET fiber.

and fiber-reinforced concrete mixtures were manufactured in a conventional rotary drum mixer. The mixing sequence was as follows:

- The coarse aggregate was placed in the mixer and the mixer was started;

- $80 \%$ of the water was added with the plasticizer;

- The cement was added;

- The fine aggregate and the remainder of the water were then added; and

- Finally, the PET fibers were added gradually to avoid bunching of the fibers in the mix.

Fresh reference and fiber mixes were tested for workability by the slump test method ${ }^{20}$. Specimens for hardened material tests were manufactured by casting fresh concrete into prismatic molds in layers of less than $75 \mathrm{~mm}$ thickness. Each layer was compacted through external vibration to avoid preferential alignment and to provide non-uniform fiber distribution ${ }^{21,22}$. The specimens were kept covered in the molds for two days and were then demolded and moist-cured until being tested after 28 and 150 days. To determinate the compressive strength and elastic modulus, the samples were cast into cylindrical shapes with a $10 \mathrm{~cm}$ diameter and $20 \mathrm{~cm}$ height. The molds were cleaned and internally oiled with a thin layer of mineral oil. The concrete was placed into the mold and manually densified with 12 strokes, according to the specifications of Brazilian Standard NBR 5738 ${ }^{23}$. After densification, the molds were covered with a waterproof material to prevent the evaporation of the concrete constitution water. The samples remained in the molds for 24 hours, and after being removed from the molds, they were identified and stored in tanks with water for 28 and 150 days (aging testing).

The flexural load-deflection behavior test was performed on three $150 \mathrm{~cm} \times 150 \mathrm{~cm} \times 500 \mathrm{~cm}$ prismatic specimens (ASTM-C.1018, three-point loading) ${ }^{19}$. Toughness indices were calculated according to ASTM Standard C.1018 22 (i.e., $\mathrm{I}_{5}, \mathrm{I}_{10}, \mathrm{I}_{20}$ and $\mathrm{I}_{30}$, which are the numbers obtained by dividing the area up to a deflection of 3.0, 5.5, 10.5 and 15.5 times, respectively, the first-crack deflection by the area up to the first crack) and ACI 544.2R-89 recommendations ${ }^{24}$ (i.e., division of the energy absorbed by the fiber-reinforced concrete and that absorbed by the plain concrete).

The drop-weight impact strength test was performed on three cylindrical specimens of $150 \mathrm{~mm}$ diameter and
$63.5 \mathrm{~mm}$ height according to the recommendation of ACI Committee $544^{24}$. This test consists of repeatedly dropping a hammer from a height of $457 \mathrm{~mm}$ onto a steel ball supported by the specimen while observing the formation of cracks and the failure of the sample. The number of blows required to cause the first visible crack on top and the ultimate failure are both recorded.

For the SEM observations, a Philips SEM XL-30 microscope equipped with an energy-dispersive X-ray analyzer (EDXA) was used, and the samples were extracted from the core of the flexural test of select 150-and 365-day-old fiber-reinforced concrete specimens. The samples were dried on silica gel under vacuum and covered with a thin gold layer before observation.

The evaluation of the porosity was accomplished using MIP and a Micromeritics Auropore III 9420 porosimeter capable of applying a maximum pressure of intrusion of $414 \mathrm{MPa} ; 1 \mathrm{~cm}^{3}$ samples were used for the testing.

The compressive strength test was performed according to the ASTM C $1231^{25}$ specifications. For each concrete type and aging time (28 and 150 days), three specimens were tested under the saturation water condition. An electric-hydraulic testing machine with 200 t capacity was used with a $0.5 \mathrm{MPa} / \mathrm{s}$ loading rate. The Young's modulus was determined from the stress-strain curve obtained from the compressive strength test. The modulus was determined by the tangent between the initial $0.5 \mathrm{MPa}$ stress at $30 \%$ of the concrete strength. The concrete compressive strength was obtained by an average of the two strength tests performed previously.

\section{Results and Discussion}

The workability test results are presented in Table 1. As expected, a greater slump loss occurred as the fiber content increased. However, workability was not diminished to the extent indicated by the slump reduction due to the limitations of the static slump test ${ }^{6}$. PET-fiber-reinforced concrete still exhibited good workability and was readily compacted without excessive vibration.

The mechanical properties (compressive strength, flexural strength, modulus of elasticity) of the concrete are presented in Table 4. For the $20 \mathrm{~mm}$ fibers, a significant increase was observed in the flexural strength after 28 days, which is in agreement with statistical analysis (ANOVA) ${ }^{18}$. An increase in the compressive strength was observed for the samples after 28 days, while a decrease was observed after 150 days. These results are in agreement with a previous study that showed that synthetic fiber addition does not increase the compressive strength of concretes and mortars ${ }^{15}$. However, small increases can be observed in some cases ${ }^{10,11}$, whereas a small reduction in the compressive strength has been verified in others ${ }^{29}$, indicating degradation signals of the PET fibers in the alkaline environment of the cement ${ }^{13,14}$. This behavior depends on the fiber geometry as well as the dispersion and adherence of the PET fibers in the cement matrix. Fraternali et al. ${ }^{10}$ obtained significant increases in compressive and flexural strengths using PET monofilaments with $1 \%$ fiber volume fraction (diameters ranging from $0.12-2.00 \mathrm{~mm}$ ). However, Kim et al. ${ }^{30}$ observed that recycled PET fibers $(0.2-1.3 \mathrm{~mm}$ diameter, $50 \mathrm{~mm}$ 
Table 4. Mechanical properties of the concretes.

\begin{tabular}{ccccc}
\hline Age (days) & $\begin{array}{c}\text { Fiber content, 20 mm } \\
\text { (volume \%) }\end{array}$ & $\begin{array}{c}\text { Compressive strength } \\
\text { (MPa) }\end{array}$ & Modulus of elasticity (GPa) & Flexural strength (MPa) \\
\hline \multirow{2}{*}{28} & 0 & $29.23 \pm 1.4$ & $24.93 \pm 3.5$ & $3.75 \pm 0.04$ \\
& 0.05 & $28.35 \pm 0.5$ & $25.05 \pm 1.1$ & $4.30 \pm 0.17$ \\
& 0.18 & $27.04 \pm 1.1$ & $22.92 \pm 0.9$ & $4.26 \pm 0.28$ \\
& 0.30 & $29.52 \pm 0.6$ & $24.20 \pm 1.4$ & $4.47 \pm 0.28$ \\
\hline \multirow{2}{*}{150} & 0 & $32.23 \pm 0.3$ & $27.15 \pm 2.1$ & $-6.67 \pm 0.24$ \\
& 0.05 & $32.52 \pm 0.2$ & $26.36 \pm 0.2$ & $4.61 \pm 0.17$ \\
\end{tabular}

length, $0.5-1.0 \%$ fiber volume fraction) added to structural concrete exhibited a slight decrease in compressive strength and elastic modulus as the fiber volume fraction increased.

A small increase in the compressive strength in the samples aged for 150 days was observed relative to those aged for 28 days. Therefore, the increase in resistance due to the cement addition was higher than the loss of resistance due to the fiber deterioration. This result can be explained by the fact that fibers do not influence the resistance to compression but only the tensile strength, where the property reduction with the time is clearly observed. Young's modulus also did not change with respect to the fiber content or the age of the samples. However, the tensile strength obtained from the flexure tests increased with an increase in the fiber content. The same behavior was not observed for the samples aged for 150 days; in addition, no increase in strength with time was observed, indicating that the effect of the presence of the fibers in the cement matrix was reduced.

The flexural load-deflection curves for the plain and fiber-reinforced concrete are plotted in Figure 2 for the 28-and 150-day-old specimens. The toughness behavior is presented in Table 5. For the 28-day-old concretes (Figure 2 and Table 5), the addition of recycled-bottle-PET fibers enhanced the energy absorption and toughness characteristics of the concrete under flexural load only for the 0.18 and $0.30 \%$ fiber volume content. This result was expected and is in agreement with results reported in the literature for similar volume fractions (i.e., 0.2-0.5\%) of other types of polymeric fibers (e.g., polypropylene) $)^{4,6,7,26,27}$. Fraternali et al. ${ }^{10}$ used PET monofilaments with diameters ranging from $0.12-2.00 \mathrm{~mm}$ (1\% fiber volume fraction) and observed a $40 \%$ increase in fracture toughness $\left(\sim 55 \mathrm{MPa}^{1 / 2}\right)$. Moreover, significant increases in compressive and flexural strengths were also obtained. The increase in the toughness index was significant for fibers measuring $20 \mathrm{~mm}$ in length, according to calculations made using the ACI recommended method (Figure 3) and statistical analysis by analysis of variance (ANOVA, with 95\% confidence interval), presented in Table 6.

However, at 150 days of age, the PET-fiber-reinforced concrete exhibited a large reduction in toughness (Table 5). Its flexural load-deflection behavior became almost identical to that of the reference concrete. This phenomenon is due to PET fiber embrittlement and degradation in the alkaline cement environment, as observed previously for polyester-fiber-reinforced concrete ${ }^{12-15}$. When comparing

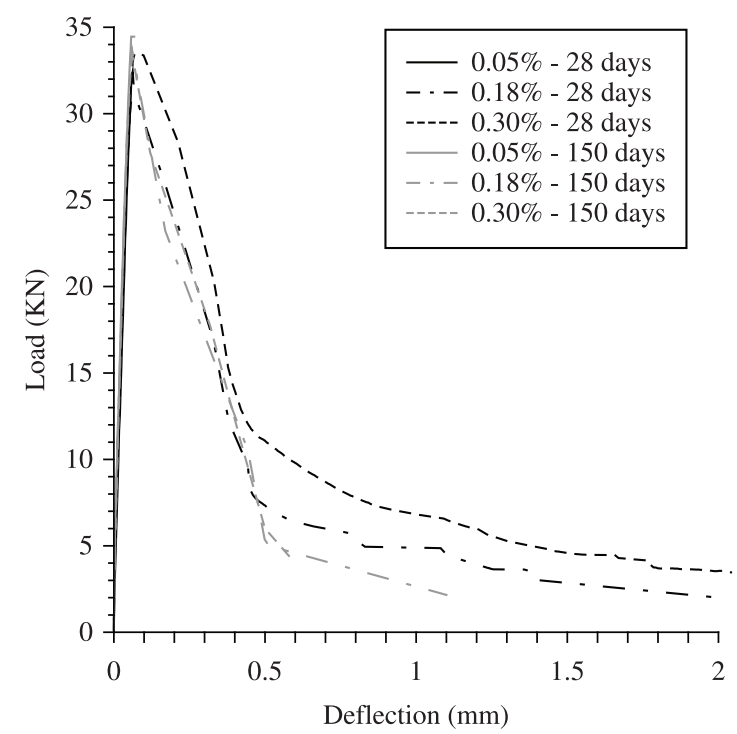

Figure 2. Concrete flexural load-deflection curves for different fiber volume fractions at 28 and 150 days (mean of three identical samples per mix).

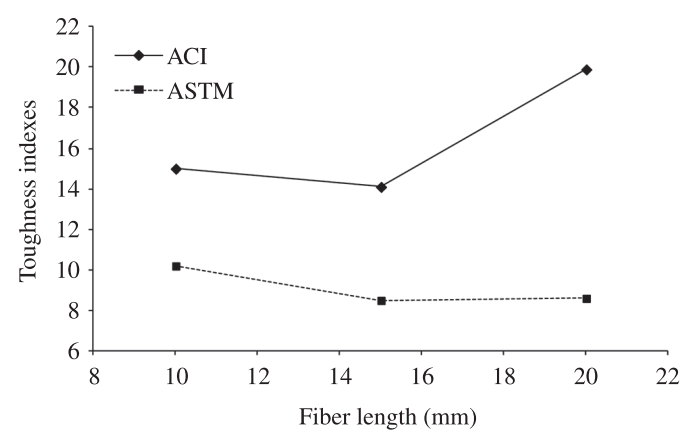

Figure 3. Toughness indices (ASTM-C.1018 - ACI-544.2R) for 0.30 fiber vol. $\%$ at 28 days.

the results obtained in this work for 15 and $20 \mathrm{~mm}$ fibers at $0.30 \%$ volume fraction with the results of a study conducted by Balaguru \& Slatum ${ }^{12}$, similar toughness indices were observed (Table 7). Moreover, in their study, the toughness indices of all the synthetic fibers presented increased over time, with the exception of the PET fibers. The authors noticed an increase in the fracture toughness as well as an increase related to the cement hydration. However, at 
Table 5. Flexural load-deflection characteristics for the reference and PET-fiber-reinforced concretes with different fiber volumes, according to the ASTM-C 1018 standard $^{20}$ and ACI 544.2R-89 recommendations ${ }^{21}$, at 28 and 150 days (mean of three identical samples per mix).

\begin{tabular}{|c|c|c|c|c|c|c|c|c|c|c|c|c|}
\hline \multirow[b]{2}{*}{$\begin{array}{c}\text { Age } \\
\text { (days) }\end{array}$} & \multicolumn{4}{|c|}{ PET (fibers) } & \multicolumn{8}{|c|}{ Toughness indexes (ASTM-C.1018 - ACI-544.2R) } \\
\hline & $\begin{array}{c}\mathbf{L} \\
(\mathbf{m m})\end{array}$ & $\begin{array}{c}V_{f} \\
(\%)\end{array}$ & $\begin{array}{c}\text { Load } \\
(\mathrm{kN})\end{array}$ & $\begin{array}{c}\text { Energy } \\
\text { at first- } \\
\text { crack } \\
\text { (N.m) }\end{array}$ & $\mathbf{I}_{5}$ & $I_{10}$ & $\mathbf{I}_{20}$ & $I_{30}$ & $\mathbf{R}_{5,10}$ & $R_{10,20}$ & $\mathbf{R}_{20,30}$ & $\begin{array}{l}\mathbf{I}_{\text {тот }} \\
\mathbf{A C I}\end{array}$ \\
\hline \multirow[t]{5}{*}{ Ref. } & - & - & 29.43 & 1.14 & - & - & - & - & - & - & - & - \\
\hline & & 0.05 & 28.59 & 1.23 & - & - & - & - & - & - & - & - \\
\hline & 10 & 0.18 & 30.06 & 1.25 & 2.90 & 4.24 & 5.74 & 6.46 & 26.80 & 15.00 & 3.6 & 10.1 \\
\hline & & 0.30 & 32.73 & 1.22 & 4.13 & 5.42 & 8.29 & 10.16 & 25.80 & 28.75 & 9.33 & 14.6 \\
\hline & & 0.05 & 30.85 & 1.21 & - & - & - & - & - & - & - & - \\
\hline \multirow[t]{5}{*}{28} & 15 & 0.18 & 30.14 & 1.22 & - & - & - & - & - & - & - & - \\
\hline & & 0.30 & 34.80 & 1.80 & 6.12 & 6.58 & 7.20 & 8.49 & 9.07 & 6.20 & 6.48 & 14.1 \\
\hline & & 0.05 & 31.78 & 1.27 & - & - & - & - & - & - & - & - \\
\hline & 20 & 0.18 & 31.05 & 1.48 & 5.74 & 6.58 & 8.27 & 9.38 & 13.47 & 13.87 & 5.58 & 12.3 \\
\hline & & 0.30 & 33.52 & 2.00 & 4.40 & 5.06 & 7.23 & 8.73 & 13.20 & 21.67 & 7.52 & 15.3 \\
\hline \multirow[t]{5}{*}{ Ref. } & - & - & - & - & - & - & - & - & - & - & - & - \\
\hline & & 0.05 & - & - & - & - & - & - & - & - & - & - \\
\hline & 10 & 0.18 & 32.12 & 1.50 & 3.27 & 5.87 & 7.96 & - & 51.93 & 20.97 & - & - \\
\hline & & 0.30 & 32.78 & 1.54 & 2.88 & 4.59 & 6.26 & - & 34.20 & 16.70 & - & - \\
\hline & & 0.05 & 32.58 & 1.48 & 2.50 & 4.19 & - & - & 33.80 & 36.95 & - & - \\
\hline \multirow[t]{5}{*}{150} & 15 & 0.18 & 34.94 & 1.30 & 2.85 & 4.45 & - & - & 32.00 & 34.30 & - & - \\
\hline & & 0.30 & 30.86 & 1.39 & 2.33 & 3.30 & 4.76 & - & 19.40 & 14.55 & 4.30 & - \\
\hline & & 0.05 & 34.17 & 1.42 & 2.09 & 3.28 & - & - & 21.00 & - & - & - \\
\hline & 20 & 0.18 & 35.38 & 1.50 & 3.25 & 5.33 & 6.50 & 7.38 & 41.60 & 11.70 & 4.43 & - \\
\hline & & 0.30 & 33.31 & 1.44 & 3.20 & 5.54 & 7.41 & - & 4673 & 15.60 & - & - \\
\hline
\end{tabular}

Table 6. Statistical analysis for the toughness indices of the PET-reinforced CRF $\left(\mathrm{V}_{\mathrm{f}}=0.30 \%\right)$ at 35 days by ANOVA.

\begin{tabular}{ccccc}
\hline Variable & Sum of squares effect & Sum of squares error & Statistics, F & Statistics, $\mathbf{p}$ \\
\hline $\begin{array}{c}\text { Fiber length } \\
\text { ACI-544.2R }\end{array}$ & 24.64008 & 3.387356 & 7.274134 & 0.024896 \\
$\begin{array}{c}\text { Fiber length } \\
\text { ASTM-C.1018 }\end{array}$ & 2.42389 & 0.579053 & 4.185950 & 0.072763 \\
\hline
\end{tabular}

Table 7. Toughness indexes for evaluation of the concrete durability at advanced age $\mathrm{e}^{12,18}$.

\begin{tabular}{cccccccc}
\hline \multirow{2}{*}{$\begin{array}{c}\text { Toughness } \\
\text { indexes }\end{array}$} & Types of fibers & \multicolumn{5}{c}{ Age in weeks (after 28 days of cure) } \\
\cline { 3 - 8 } & & $\mathbf{0}$ & $\mathbf{4}$ & $\mathbf{8}$ & $\mathbf{1 6}$ & $\mathbf{3 2}$ & $\mathbf{5 2}$ \\
\hline \multirow{3}{*}{$\mathrm{I}_{30}$} & ${\text { Nylon } 6{ }^{12}}$ & 16.4 & 15.8 & 38.9 & 27.0 & 27.9 & 20.8 \\
& Polypropylene $^{12}$ & 20.7 & 24.6 & 38.2 & 36.1 & 32.6 & 31.1 \\
& Polyester $^{12}$ & 10.1 & 10.9 & 7.5 & 7.8 & 9.7 & 7.4 \\
& PET 20 mm $(0.30 \%)^{[18]}$ & 8.73 & - & - & - & - & - \\
\hline
\end{tabular}

52 weeks of age, they noticed a decrease in the fracture toughness, indicating fiber deterioration. The decrease of the fracture toughness at 21 and 52 weeks in this study in comparison to the Balaguru \& Slatum study ${ }^{12}$ can be associated to the material used to produce the fibers by extrusion, the fiber geometry, and the type of cement used.

Although it is well known that the drop-weight impact strength test is subject to important variations $s^{7,24,26,28}$, Figure 4 clearly demonstrates that at 28 days of age, concrete impact toughness increased with larger fiber volume fractions. Multiple comparisons of the data means indicated that the fibers did not affect the impact resistance to the first crack and that the impact resistance at failure was significantly different from the reference concrete only with the addition of 0.18 and $0.30 \%$ fiber volume fractions for a $95 \%$ level of confidence.

However, at 150 days, the behavior of the PET-fiberreinforced concrete was similar to the reference concrete of 


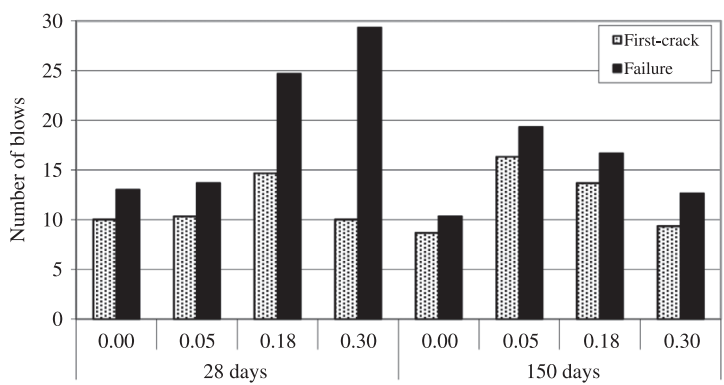

Figure 4. Impact resistance test results for the reference and PET-fiber-reinforced concretes with different fiber volume fractions at 28 and 150 days (mean of three identical samples per mix).

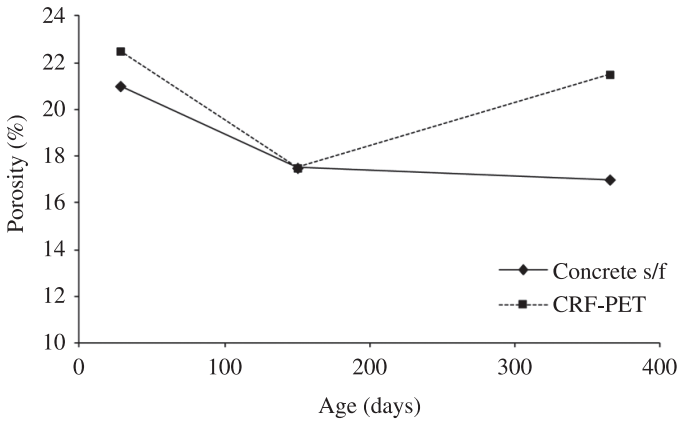

Figure 5. Porosity test results for the reference and PET-fiber-reinforced concretes.

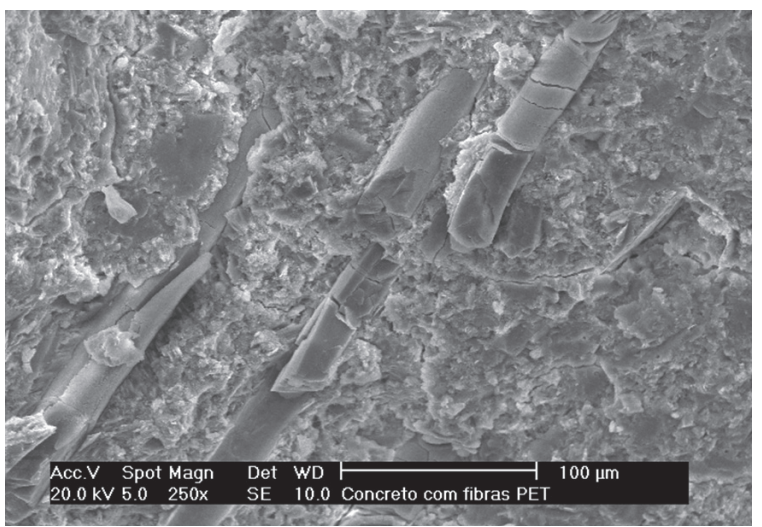

(a) the same age (i.e., as a brittle material), as demonstrated by the decrease in the impact resistance at failure (Figure 4). This result indicated that the PET fibers no longer had an effect because of their degradation in the alkaline concrete environment.

Signs of degradation were observed in the mercury intrusion porosity assays, in which two concrete samples were compared: the reference, without fibers, and $0.30 \%$ volume fraction addition of $20 \mathrm{~mm}$ fibers. The results revealed equivalent porosities, both after 28 and 150 days, as observed in Table 8 and Figure 5. Moreover, after one year, greater concrete porosity was observed in the PET-fiber-reinforced concrete than in the reference sample. This additional test performed at an advanced age (1 year) revealed that the PET fiber degradation in the alkaline environment of the cement is a slow process, and the measurement of that property for PET fibers in concretes and mortars could be difficult to achieve in short periods of time. Therefore, sometimes an extended time is demanded, as in this case. SEM observations of the PET fibers after aging for 150 days (Figure 6) and one year (Figure 7) in the concrete samples revealed a high degree of fiber deterioration.

Therefore, this work provided results about the low durability of PET fibers in the alkaline environment of the concrete. However, the durability and mechanical performance of the PET fibers in the alkaline environment of the concretes and mortars can exhibit different behaviors depending on the characteristics of the production process, which affects the fiber-cement matrix interaction.

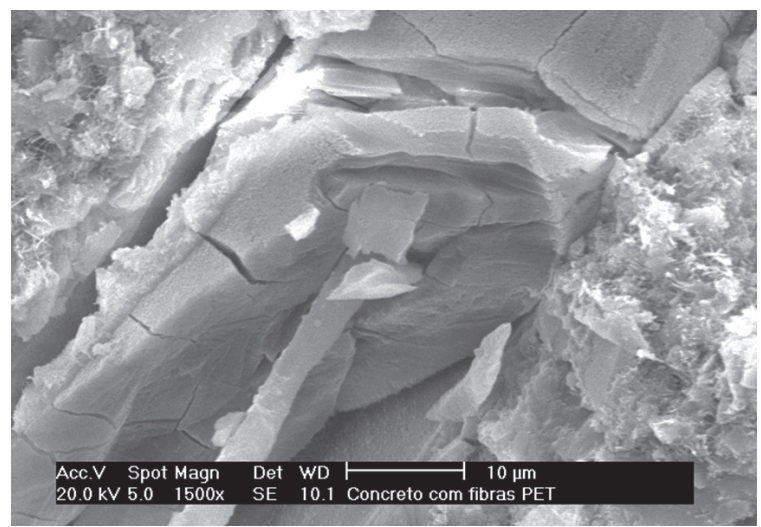

(b)

Figure 6. SEM micrographs showing the PET fibers in the process of degradation after 150 days in the alkaline concrete environment. Magnification of: a) $250 \times$ and b) $1500 \times$.

Table 8. Results of the mercury intrusion porosimetry (MIP) test ( $\mathrm{Vf}=0.30 \%$ and fibers length $=20 \mathrm{~mm})$.

\begin{tabular}{|c|c|c|c|c|c|c|c|}
\hline \multirow{2}{*}{\multicolumn{2}{|c|}{ Properties }} & Concrete & CRF-PET & Concrete & CRF-PET & Concrete & CRF-PET \\
\hline & & \multicolumn{2}{|c|}{28 days } & \multicolumn{2}{|c|}{150 days } & \multicolumn{2}{|c|}{365 days } \\
\hline \multicolumn{2}{|c|}{ Porosity $(\%)$} & 21.08 & 22.67 & 17.44 & 17.34 & 17.06 & 21.51 \\
\hline \multicolumn{2}{|c|}{ Average pore diameter - volume $(\mu \mathrm{m})$} & 0.1115 & 0.1149 & 0.0388 & 0.0312 & 0.0625 & 0.1100 \\
\hline \multicolumn{2}{|c|}{ Average pore diameter - area $(\mu \mathrm{m})$} & 0.0176 & 0.0141 & 0.0150 & 0.0113 & 0.0123 & 0.018 \\
\hline \multirow{4}{*}{$\begin{array}{c}\text { Pores for } \\
\text { diameter }(\%)\end{array}$} & $<10 \mathrm{~nm}$ & 5.09 & 6.17 & 8.99 & 15.12 & 10.39 & 5.35 \\
\hline & $10-50 \mathrm{~nm}$ & 20.17 & 19.42 & 49.60 & 47.33 & 32.97 & 19.62 \\
\hline & $0.05-1 \mu \mathrm{m}$ & 70.31 & 66.42 & 36.41 & 28.49 & 47.67 & 64.52 \\
\hline & $>1 \mu \mathrm{m}$ & 4.44 & 8.00 & 5.00 & 9.07 & 8.96 & 10.50 \\
\hline
\end{tabular}




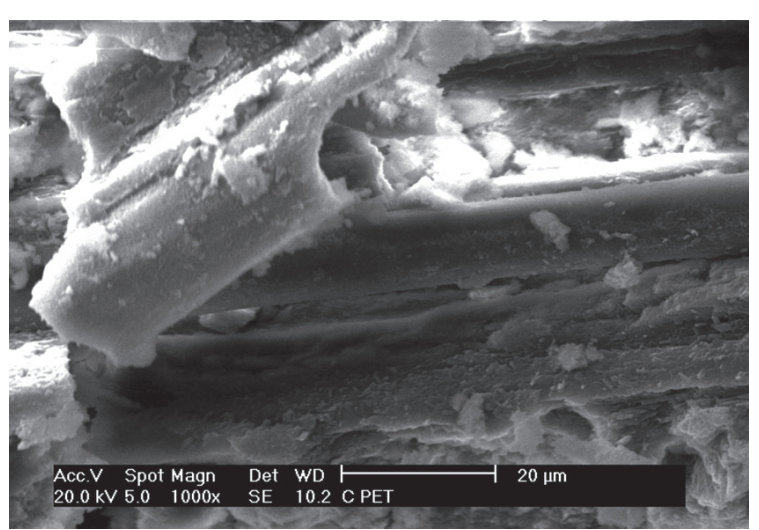

(a)

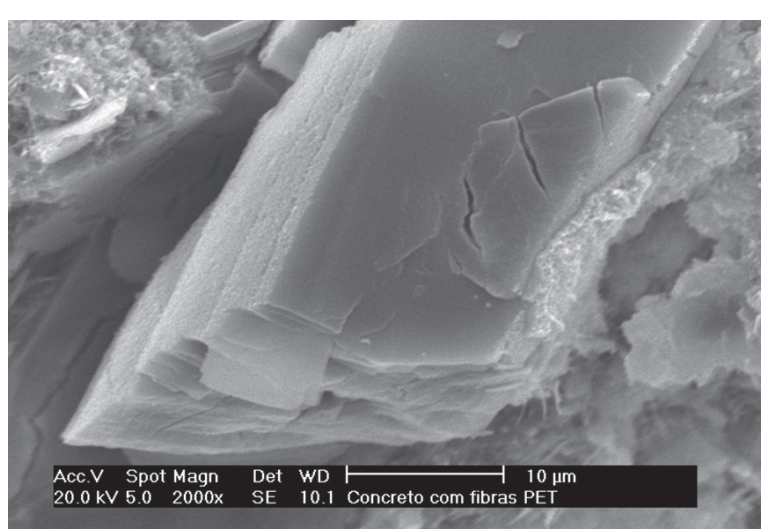

(b)

Figure 7. SEM micrograph showing PET fibers presenting intense degradation after one year in the alkaline concrete environment. Magnification of: a) $1000 \times$ and b) $2000 \times$.

\section{Conclusions}

Based on the results of this experimental investigation, it can be concluded that at a fiber volume fraction content of $0.18 \%$ and $0.30 \%$, though not $0.05 \%, 20 \mathrm{~mm}$ long recycled-bottle-PET fibers increased the flexural and impact toughness of 28-day-old conventional concrete. However, at 150 days, this toughness improvement was no longer present due to the embrittlement and degradation of the recycled-bottle-PET fibers in the alkaline concrete environment, as visualized by SEM observations (150 and 365 days old). The values of the compressive strength and Young's modulus were not influenced by the PET fibers; however, the tensile strength increased with the increase of

\section{References}

1. Massicotte B and Bischoff PH. Fibre Reinforced Concretes: A Structural Perspective. In: Proceedings of the Fifth International RILEM Symposium - BEFIB' 2000; 2000; Lyon, France. Lyon: RILEM Publications; 2000. p. 193-202.

2. Mindess $\mathrm{S}$ and Banthia N. Fiber reinforced cementitious composites: current practice and future prospects. In: Malhorta VM and Mehta PK. Concrete Technology: past, present, and future. Michigan: American Concrete Institute; 1993. p. 417-446.

3. Taylor GD. Materials in Construction. 2nd ed. London: Longman Scientific \& Technical; 1994.

4. Johnston CD. Fibre-reinforced cement and concrete. In: Malhorta VM. Advances in concrete technology. 2nd ed. Ottawa: Gordon and Breach Publishers; 1994. p. 603-673.

5. Hannant DJ. Fibre-reinforced cements and concretes. In: Illston JM and Domone P, editors. Construction Materials: their nature and behavior. 2nd ed. London: E \& FN Spon; 1994. p. 359-403.

6. Bentur A and Mindess S. Fibre Reinforced Cementitious Composites. London: Elsevier Science Publishers; 1990.

7. Bayasi Z and Zeng J. Properties of polypropylene fiber reinforced concrete. ACI Material Journal. 1993; 90:605-610.

8. Pliya P, Beaucour A-L and Noumowé A. Contribution of cocktail of polypropylene and steel fibres in improving the behaviour of high strength concrete subjected to high temperature. the fiber content, despite a decrease in the effect at 150 days. Considering the important aspects of sustainability, such as the use of recycled materials in civil construction, this work contributes to a better understanding of the durability of fine, multifilament-type fibers obtained from recycled PET bottles in the alkaline environment of concrete.

\section{Acknowledgements}

The authors are grateful to the Coordenação de Aperfeicoamento de Pessoal de Nível Superior (CAPES) and to the Conselho Nacional de Desenvolvimento Científico e Tecnológico (CNPq) for supporting this work.
Construction and Building Materials. 2011; 25:1926-1934. http://dx.doi.org/10.1016/j.conbuildmat.2010.11.064

9. Nili M and Afroughsabet V. The effects of silica fume and polypropylene fibers on the impact resistance and mechanical properties of concrete. Construction and Building Materials. 2010; 24: 927-933. http://dx.doi.org/10.1016/j. conbuildmat.2009.11.025

10. Fraternali F, Ciancia V, Chechile R, Rizzano G, Feo L and Incarnato L. Experimental study of the thermo-mechanical properties of recycled PET fiber-reinforced concrete. Composite Structures. 2011; 93:2368-2374. http://dx.doi. org/10.1016/j.compstruct.2011.03.025

11. Patel JK, Desai NB and Rana JC. Fibre reinforced cements and concretes: recent developments. London: Elsevier Applied Science; 1989. p. 306-315.

12. Balaguru P and Slattum K. Test methods for durability of polymeric fibers in concrete and UV light exposure. ACI-SP.155; 1995. p. 115-136.

13. Wang Y, Backer S and Li VC. An experimental study of synthetic fibre reinforced cementitious composites. Journal of Material Science. 1987; 22:4281-4291. http://dx.doi. org/10.1007/BF01132019

14. Houget V. Etude des caractéristiques mécaniques et physico-chimiques de composites ciments-fibres organiques. [Thesis]. Lyon: Institut National des Sciences Appliquées; 1992. 
15. Silva DA, Betioli AM, Gleize PJP, Roman HR, Gomes LA and Ribeiro JLD. Degradation of recycled PET fibers in Portland cement-based materials. Cement and Concrete Research. 2005; 35:1741-1746. http://dx.doi.org/10.1016/j. cemconres.2004.10.040

16. Won J-P, Jang C-I, Lee S-W, Lee S-J and Kim H-Y. Long-term performance of recycled PET fibre-reinforced cement composites. Construction and Building Materials. 2010; 24:660-665. http://dx.doi.org/10.1016/j. conbuildmat.2009.11.003

17. Ochi T, Okubo S and Fukui K. Development of recycled PET fiber and its application as concrete-reinforcing fiber. Cement and Concrete Composite. 2007; 29:448-455. http://dx.doi. org/10.1016/j.cemconcomp.2007.02.002

18. American Concrete Institute - ACI Committee. ACI 544.1R-96: State-of-the-Art Report on Fiber Reinforced Concrete. Detroit: ACI Committee; 1996. chap. 4.

19. Pelisser F. Avaliação do desempenho de concreto reforçado com fibras de poli-etileno tereftalato. [Dissertação]. Florianópolis: Universidade Federal de Santa Catarina; 2002. (in Portuguese).

20. Associação Brasileira de Normas Técnicas - ABNT. NBR-5733: Cimento Portland de alta resistência inicial. Rio de Janeiro: ABNT; 1991. (in Portuguese).

21. Associação Brasileira de Normas Técnicas - ABNT. NBR-7223: Concreto - Determinação da consistência pelo abatimento do tronco de cone. Rio de Janeiro: ABNT; 1994. (in Portuguese).

22. Associação Brasileira de Normas Técnicas - ABNT. NBR-5738: Moldagem e cura de corpos de prova cilíndricos ou prismáticos de concreto. Rio de Janeiro: ABNT; 1994. (in Portuguese).
23. American Society for Testing and Materials - ASTM. ASTM-C1018: Flexural Toughness and First-Crack Strength of Fiber - Reinforced Concrete. West Conshohocken: ASTM; 1997.

24. Associação Brasileira de Normas Técnicas-ABNT. NBR-5738: Moldagem e cura de corpos de prova cilíndricos ou prismáticos de concreto. Rio de Janeiro: ABNT; 1994. 9 p. (in Portuguese).

25. American Concrete Institute - ACI Committee. ACI-544.2R-89: Measurement of properties of fiber reinforced concrete. Detroit: ACI Committee; 1989.

26. American Society for Testing and Materials - ASTM. ASTM-C1231: Standard Practice for Use of Unbonded Caps in Determination of Compressive Strength of Hardened Concrete Cylinders. West Conshohocken: ASTM; 2010.

27. Alhozaimy AM, Soroushian F and Mirza F. Mechanical properties of polypropylene fiber reinforced concrete and the effects of pozzolanic materials. Cement and Concrete Composites. 1996; 18:85-92. http://dx.doi. org/10.1016/0958-9465(95)00003-8

28. Zheng $\mathrm{Z}$ and Feldman D. Synthetic fibre-reinforced concrete. Progress in Polymer. 1995; 20:185-210. http://dx.doi. org/10.1016/0079-6700(94)00030-6

29. Soroushian P, Khan A and Hsu J. Mechanical properties of concrete materials reinforced with polypropylene or polyethylene fibers. ACI Material Journal. 1992; 89(6):535-540.

30. Kim SB, Yi NH, Kim HY, Kim JHJ and Song Y-C. Material and structural performance evaluation of recycled PET fiber reinforced concrete. Cement and Concrete Composites. 2010; 32(3):232-240. http://dx.doi.org/10.1016/j. cemconcomp.2009.11.002 